\title{
Herbal teas as a rich source of phenolic compounds
}

Ingrīda Augšpole*,

Māra Dūma,

Ingmārs Cinkmanis,

\section{Baiba Ozola}

Department of Chemistry,

Faculty of Food Technology,

Latvia University of Life Sciences

and Technologies,

Lielā iela 2, Jelgava 3001, Latvia
Phenolic compounds are of a considerable interest and have received more and more attention in recent years due to their bioactive functions. These components are known as secondary plant metabolites and also possess antimicrobial, antiviral and anti-inflammatory properties. The popular Latvian herbals - Calendula (Calendula officinalis L.), Lady's-mantle (Alchemilla vulgaris L.), Yarrow (Achillea millefolium L.), Peppermint (Mentha $\times$ piperita L.) and Bellis (Bellis perennis L.) - are widely used for herbal teas. The objective of this study was to determine individual phenolic compounds in herbal infusions using high-performance liquid chromatography. The obtained results showed significant differences $(p<0.05)$ of the phenolics content in the analysed herbal teas. The total content of the identified 14 phenolic compounds in Yarrow tea was on the average

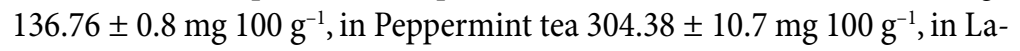

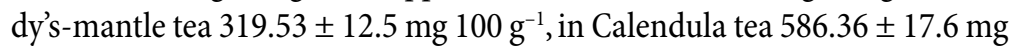
$100 \mathrm{~g}^{-1}$, but in Bellis tea it was $802.96 \pm 21.3 \mathrm{mg} 100 \mathrm{~g}^{-1}$. The dominant phenolic compound in Peppermint, Lady's-mantle and Yarrow teas was rutin, but chlorogenic acid in Bellis tea. Calendula tea has an abundant quantity of sinapic acid.

Keywords: herbal teas, phenolic compounds, HPLC

\section{INTRODUCTION}

Herbs are used in many domains, including medicine, nutrition, flavouring, beverages, dyeing, fragrances and cosmetics [1]. Tea consumption has a long history and tea is popular in some Asian, South American and European countries, as a beverage and as herbal medicine. Since the last decades, tea has emerged as a popular source of dietary antioxidants and its effects are being investigated by in vitro and in vivo methods [2]. Herbal infusions, including teas, are highly consumed drinks; their importance lies not only in their hydrating capacity but also in their beneficial properties [3, 4].

Unlike most other forms of tea, herbal teas do not contain caffeine. They also taste great and are

* Corresponding author. Email: ingrida.augspole@llu.lv easy to drink. Most herbal teas may consist of one main herbal ingredient or a blend of herbal ingredients, intended to bring about a specific purpose, such as relaxation, rejuvenation and relief from a specific condition, amongst other things [5].

Plants and derived products have many beneficial properties, which are associated with the presence of secondary metabolites, especially phenolic compounds [6]. Phenolic compounds possess multiple biological activities, including biochemical activities such as antimutagenic, antioxidant and anticarcinogenic, in addition to having the ability to modify gene expression [7]. Polyphenols are compounds with phenolic structural features. The polyphenols contain subgroups of phenolic compounds, that in plants are present (in the majority) in the form of glycosides. The classification of polyphenols has been made by a chemical structure, origin and biological function. One 
of the classifications according to the chemical structures of aglycones comprise phenolic acids (mainly benzoic acid and cinnamic acid derivatives), flavonoids (isoflavones, neoflavonoids and chalcones, flavones, flavonols, flavanones and flavanonols, flavanols and proanthocyanidins, anthocyanidins) and polyphenolic amides [8]. Phenolics comprise a large group of biologically active ingredients - from simple phenol molecules to polymeric structures with molecular mass above 30000 Ds. On the basis of the number of phenol subunits, the modern classification forms two basic groups of phenolics - simple phenols and polyphenols. The group of simple phenols also contains the so-called 'phenolic acids' or phenols with a carboxyl group determining their specific function [7].

Tea polyphenols include flavonols (quercetein, kaempferol, myricetin), flavan-3-ols (catechins and theaflavins), a small amount of purine alkaloids (caffeine and theobromine), gallic acid derivatives (gallic acid, 5-galloylquinic acid) and hydroxycinammate quinic esters (caffeoylquinic acids). Among them, catechins and theaflavins are the two common indices used to determine the antioxidant ability of tea [9, 10].

Phenolic compounds are ubiquitous in plants which collectively synthesize several thousand different chemical structures characterized by hydroxylated aromatic ring(s). These compounds play several important functions in plants. They represent a striking example of metabolic plasticity enabling plants to adapt to changing biotic and abiotic environments and provide to plant products colour, taste, technological properties and putative health promoting benefits [11]. Some soluble phenolics are widely distributed, e.g. chlorogenic acid, but the distribution of many other structures is restricted to specific genera or families making them convenient biomarkers for taxonomic studies. Their common feature is the presence of a hydroxy-substituted benzene ring within their structure [12].

In addition, flavonoids are known to inhibit lipid-peroxidation, platelet aggregation, capillary permeability and fragility, cyclooxygenase and lipoxygenase enzyme activities, flavonoids act as antioxidants, free radical scavengers or chelators of divalent cation [13]. Many species were used in folk and human medicine, because they have been recognized to have medicinal properties and beneficial impact on health, e.g. antioxidant activity, digestive stimulation action, antiinflammatory, antimicrobial, hypolipidemic, antimutagenic effects and anticarcinogenic potential [1, 6, 9, 14]. Moreover, calendula has healing and antiseptic properties with actions that are sudorific and analgesic, affect the bile duct, are antiinflammatory, antiviral and anti-emetic, and tone the skin with vasodilation [15]. Kaya et al. (2012) also indicated that flavonoids captured the interest of scientists from many different disciplines because of their structural diversity, biological and ecological significance in systematic, and health-promoting and anti-cancer properties [16]. Yarrow (Achillea millefolium L.) also traditionally has been used as an abortifacient, emmenagogue, contraceptive, and for stimulating uterine contractions. For this reason, it is contra-indicated for use in pregnancy [14].

The objective of this study was to determine individual phenolic compounds in herbal infusions using high-performance liquid chromatography.

\section{MATERIALS AND METHODS}

Investigations were carried out at the Department of Chemistry, Latvia University of Life Sciences and Technologies.

\section{Plant materials}

Plants of Calendula (Calendula officinalis L.), Lady's-mantle (Alchemilla vulgaris L.), Yarrow (Achillea millefolium L.), Peppermint (Mentha $\times$ piperita L.) and Bellis (Bellis perennis L.) were grown in Latvia's Jelgava Region (GPS-coordinates: $56^{\circ} 39^{\prime}$ 3.992" N 23 $43^{\circ} 16.874^{\prime \prime} \mathrm{E}$ ), collected during the flowering period in May till July 2017 and were dried at room temperature in a dark place. This study used flower samples from Calendula, Lady'smantle, Bellis and Yarrow, and leaves from Peppermint plants.

\section{Preparation of herbal infusions}

Infusions were prepared in triplicate using ground air-dried herbal tea materials and boiling deionized water $\left(0.055 \mu \mathrm{S} \mathrm{cm}^{-1}\right)$ for extraction. For this purpose $0.5 \pm 0.0001 \mathrm{~g}$ of finely ground air-dried plant material was extracted in $30 \mathrm{~mL}$ of boiling distilled water and stirred gently on a magnetic stirrer at 
room temperature for $15 \mathrm{~min}$. Each extract was then filtered through a paper filter $(11 \mu \mathrm{m}$, Whatman Inc., Clifton, NJ, USA). The supernatant was used for determination of individual phenolic compounds [17].

\section{Phenolic compounds, HPLC}

The analysis of individual phenolic compounds was performed with a Shimadzu HPLC system LC-20 Prominence including a Photo-diode Array detector (SPD-M20A), a Solvent Delivery Unit (LC20AD), a Column Oven (CTO-20A), an Autosampler (SIL-20A), a System Controller (CBM-20A) and the data system LCsolution software.

Preparation of calibration solution: weight in a $100 \mathrm{~mL}$ volumetric flask with a narrow neck $6.8 \pm 0.1 \mathrm{mg}$ gallic acid, $12.0 \pm 0.1 \mathrm{mg}$ catechin, $12.8 \pm 0.1 \mathrm{mg}$ 4-hydroxybenzoic acid, $13.1 \pm 0.1 \mathrm{mg}$ chlorogenic acid, $13.8 \pm 0.1 \mathrm{mg}$ caffeic acid, $16.0 \pm 0.1 \mathrm{mg}$ epicatechin, $18.8 \pm 0.1 \mathrm{mg}$ syringic acid, $9.8 \pm 0.1 \mathrm{mg}$ vanillin, $12.1 \pm 0.1 \mathrm{mg}$ p-coumaric acid, $88.1 \pm 0.1 \mathrm{mg}$ sinapinic acid, $9.2 \pm 0.1 \mathrm{mg}$ ferulic acid, $6.1 \pm 0.1 \mathrm{mg}$ rutin, $10.3 \pm 0.1 \mathrm{mg}$ trans-4-hydroxycinnamic acid and $4.3 \pm 0.1 \mathrm{mg} \mathrm{qu}-$ ercetin; then fill with HPLC grade CHROMASOLV methanol till the mark and mix.

\section{Parameters of chromatography}

The analytical column YMC C18, $4.6 \mathrm{~mm} \times$ $250 \mathrm{~mm}, 5 \mu \mathrm{m},+30^{\circ} \mathrm{C}$, was used for separation of polyphenols in the $278 \mathrm{~nm}$ wavelength. The injection volume of the sample was $100 \mu \mathrm{L}$. The mobile phase - A (deionized water), B (HPLC grade $\mathrm{CHROMASOLV}^{\circ}$ methanol) and C (acetic acid solu- tion for HPLC) in the gradient conditions - was used. The start flow rate was $1.0 \mathrm{~mL} \mathrm{~min}{ }^{-1}$. Gradient conditions: start $\mathrm{B}(0 \mathrm{~mL})$ : $\mathrm{C}(2.5 \mathrm{~mL}) ; 2 \mathrm{~min} \mathrm{~B}(15 \mathrm{~mL})$ : C $(2.4 \mathrm{~mL}) ; 12 \operatorname{min~B~}(18 \mathrm{~mL}): \mathrm{C}(2.2 \mathrm{~mL})$, flow rate $=0.8 \mathrm{~mL} \mathrm{~min}^{-1} ; 20 \mathrm{~min} \mathrm{~B}(20 \mathrm{~mL}): \mathrm{C}(1.8 \mathrm{~mL})$, flow rate $=0.6 \mathrm{~mL} \mathrm{~min}^{-1} ; 25 \mathrm{~min}$, flow rate $=0.5 \mathrm{~mL}$ $\min ^{-1} ; 30 \mathrm{~min} \mathrm{~B}(25)$ : C (1.6 mL); $35 \mathrm{~min}$, flow rate $=0.4 \mathrm{~mL} \mathrm{~min}^{-1} ; 40 \mathrm{~min} \mathrm{~B}(30 \mathrm{~mL}): \mathrm{C}(1.4 \mathrm{~mL})$; $45 \mathrm{~min}$, flow rate $=0.8 \mathrm{~mL} \mathrm{~min}^{-1} ; 50 \mathrm{~min} \mathrm{~B}(45 \mathrm{~mL})$ : $\mathrm{C}(1 \mathrm{~mL})$, flow rate $=0.7 \mathrm{~mL} \mathrm{~min}^{-1} ; 55 \mathrm{~min} \mathrm{~B}(55 \mathrm{~mL})$ : $\mathrm{C}(0.9 \mathrm{~mL})$, flow rate $=0.8 \mathrm{~mL} \mathrm{~min}^{-1} ; 65 \mathrm{~min} \mathrm{~B}(85 \mathrm{~mL})$ :

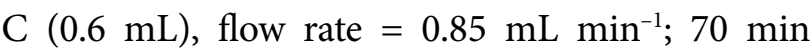
B $(100 \mathrm{~mL}): C(0 \mathrm{~mL})$, flow rate $=1.0 \mathrm{~mL} \mathrm{~min}{ }^{-1}$; $73 \mathrm{~min} B(0 \mathrm{~mL})$ : C (2.5 mL); $78 \mathrm{~min}$. STOP.

\section{Chromatogram of individual phenolic compounds: Mathematical data processing}

The results are the means and standard deviation for three replicates. Means \pm SD were compared by the analysis of variance (ANOVA). The significance was defined at $P<0.05$. The statistical analysis was carried out by the Microsoft Excel 2016 version software.

\section{RESULTS}

Flavonoids are natural products widely distributed in the plant kingdom and currently consumed in large amounts in the daily diet [12].

Flavonoid compounds in herbal tea infusions were determined in various concentrations. The dominant phenolic compound in the Peppermint, Lady'smantle and Yarrow tea was rutin. As shown in Fig. 2 the highest content of rutin was determined in

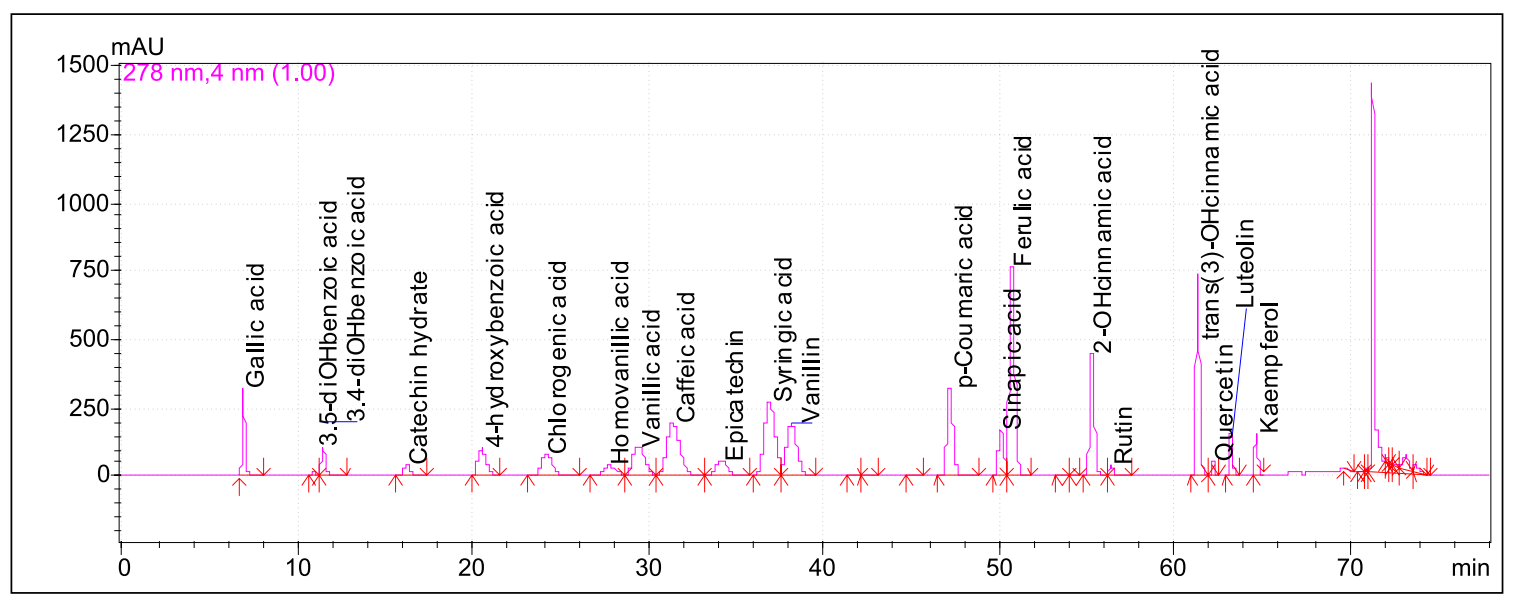

Fig. 1. The HPLC calibration chromatogram of individual phenols 


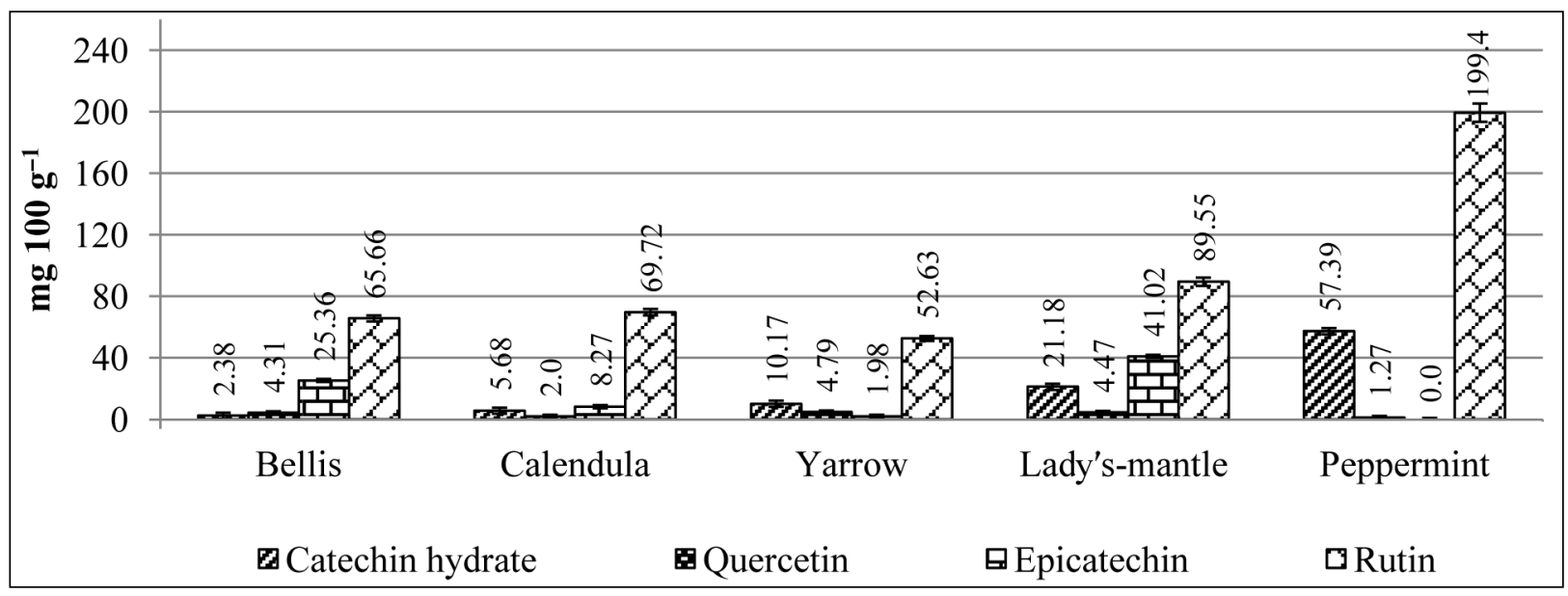

Fig. 2. Flavonoid compounds in herbal tea infusions

the Peppermint tea $-199.44 \pm 1.4 \mathrm{mg} 100 \mathrm{~g}^{-1}$. The lowest content of flavonoids (Quercetin) was in the Peppermint and Calendula tea $-1.27 \pm 0.1 \mathrm{mg} 100 \mathrm{~g}^{-1}$ and $2.0 \pm 0.3 \mathrm{mg} 100 \mathrm{~g}^{-1}$, respectively, but the content of epicatechin in the Yarrow tea was $1.98 \pm 0.1 \mathrm{mg} 100 \mathrm{~g}^{-1}$. Epicatechin was not determined in the Peppermint tea infusion.

The total content of identified flavonoids in the herbal tea infusions varied from $69.57 \pm 0.8$ to

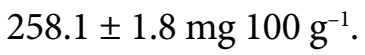

The highest concentration $(258.1 \pm 1.8$ and $156.22 \pm 1.2 \mathrm{mg} 100 \mathrm{~g}^{-1}$ ) was found in the Peppermint and Lady's-mantle herbal tea infusions, indicating a high nutritional value of the herbal tea and a possible positive effect on human health. The lowest total concentration of flavonoid compounds $\left(69.57 \pm 0.8 \mathrm{mg} 100 \mathrm{~g}^{-1}\right)$ was found in the Yarrow herbal tea infusion. Scientists (from Brock University, Canada) Cleverdon et al. (2018) reported that the Peppermint tea had the highest antioxidant capacity when testing across the bagged tea [18].

The chromatographic analysis of polyphenolic compounds in five herbal teas, Calendula ( $\mathrm{Ca}$ lendula officinalis L.), Lady's-mantle (Alchemilla vulgaris L.), Yarrow (Achillea millefolium L.), Peppermint (Mentha $\times$ piperita L.) and Bellis (Bellis perennis L.), revealed the presence of flavonoid compounds.

The conducted experiments showed the presence of several phenolic acids and aldehyde compounds in the herbal tea infusions (Table 1). The phenolic acids ( $\mathrm{p}$-coumaric acid, ferulic acid,

Table 1. Phenolic acids and aldehyde compounds in herbal tea infusions

\begin{tabular}{|c|c|c|c|c|c|}
\hline \multirow{2}{*}{$\begin{array}{l}\text { Phenolic acids and aldehyde com- } \\
\text { pounds }\end{array}$} & \multicolumn{5}{|c|}{ Herbal tea infusions } \\
\hline & Bellis & Calendula & Yarrow & Peppermint & Lady's-mantle \\
\hline & \multicolumn{5}{|c|}{$\mathrm{mg} 100 \mathrm{~g}^{-1}$} \\
\hline p-Coumaric acid & $0.28 \pm 0.01$ & $1.68 \pm 0.14$ & $2.73 \pm 0.17$ & $1.23 \pm 0.08$ & $1.48 \pm 0.01$ \\
\hline Ferulic acid & $0.39 \pm 0.01$ & N.D. & $3.63 \pm 0.25$ & $0.16 \pm 0.01$ & $3.91 \pm 0.21$ \\
\hline Syringic acid & $1.06 \pm 0.05$ & $0.81 \pm 0.01$ & $3.66 \pm 0.10$ & $1.04 \pm 0.02$ & $12.15 \pm 0.14$ \\
\hline Vanillin & $1.3 \pm 0.11$ & $1.32 \pm 0.21$ & $2.37 \pm 0.16$ & $1.88 \pm 0.09$ & $22.37 \pm 0.24$ \\
\hline Gallic acid & $1.75 \pm 0.25$ & $3.47 \pm 0.17$ & $2.85 \pm 0.25$ & N.D. & $20.66 \pm 0.15$ \\
\hline Caffeic acid & $2.14 \pm 0.21$ & $53.41 \pm 1.04$ & $1.1 \pm 0.01$ & $9.35 \pm 0.35$ & $26.19 \pm 0.28$ \\
\hline trans(3)-OHcinnamic acid & $2.77 \pm 0.19$ & $2.84 \pm 0.08$ & $50.23 \pm 0.42$ & $10.32 \pm 0.09$ & $1.34 \pm 0.01$ \\
\hline Sinapic acid & $7.5 \pm 0.10$ & $321.49 \pm 10.39$ & $0.04 \pm 0.01$ & $4.97 \pm 0.26$ & $31.22 \pm 014$ \\
\hline 4-Hydroxybenzoic acid & $13.53 \pm 0.11$ & $2.45 \pm 0.11$ & $0.58 \pm 0.01$ & $10.21 \pm 0.14$ & $3.05 \pm 0.04$ \\
\hline Chlorogenic acid & $674.53 \pm 10.21$ & $113.22 \pm 2.04$ & N.D. & $7.12 \pm 0.14$ & $40.94 \pm 0.18$ \\
\hline
\end{tabular}

${ }^{*}$ Results are reported as the mean \pm SD of three infusion preparations $(n=3)$.

${ }^{*}$ N. D., not detected. 
syringic acid, gallic acid, caffeic acid, $\operatorname{trans}(3)-\mathrm{OH}-$ cinnamic acid, sinapic acid, 4-hydroxybenzoic acid, chlorogenic acid) and aldehyde (vanillin) compounds were identified in the herbal tea infusions.

As shown in Table 1, the content of different polyphenols in the analysed samples of herbal tea infusions fluctuates within quite a large range. An increased content of sinapic acid is observed in the Calendula herbal tea $\left(321.49 \pm 10.39 \mathrm{mg} 100 \mathrm{~g}^{-1}\right)$ and that of chlorogenic

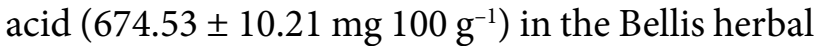
tea. The results of the chromatographic analyses show that ferulic acid in the Calendula tea and gallic acid in the Peppermint tea infusions were not quantified. The scientists Vitalini et al. (2011) from Italy also reported that chlorogenic acid in the Yarrow tea was not detected in the HPLC fraction because of its low amount [19].

It is hoped that the results obtained in this study will be useful for health and nutritional scientific disciplines.

\section{CONCLUSIONS}

1. An increased content of phenolic acids is observed: sinapic acid in the Calendula herbal tea

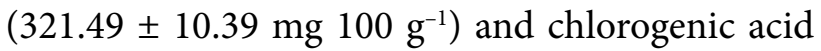
$\left(674.53 \pm 10.21 \mathrm{mg} 100 \mathrm{~g}^{-1}\right)$ in the Bellis herbal tea.

2. A higher concentration of flavonoid compounds $\left(258.1 \pm 1.8 \mathrm{mg} 100 \mathrm{~g}^{-1}\right)$ was found in the Peppermint herbal tea infusions. The lowest concentration of flavonoid compounds (69.57 mg $100 \mathrm{~g}^{-1}$ ) was found in the Yarrow herbal tea infusions.

3. The total content of the identified 14 phenolic compounds in the Yarrow tea was on the average $136.76 \pm 0.8 \mathrm{mg} 100 \mathrm{~g}^{-1}$, in the Peppermint tea it was $304.38 \pm 10.7 \mathrm{mg} 100 \mathrm{~g}^{-1}$, in the Lady's-mantle

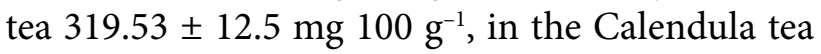

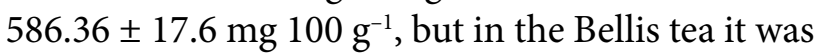
$802.96 \pm 21.3 \mathrm{mg} 100 \mathrm{~g}^{-1}$.

4. The dominant phenolic compound in the Peppermint, Lady's-mantle and Yarrow tea was rutin, but chlorogenic acid in the Bellis tea. The Calendula tea has an abundant quantity of sinapic acid.

Received 13 September 2018 Accepted 8 October 2018

\section{References}

1. L. Georgieva, A. Gadjalova, D. Mihaylova, A. Pavlov, Int. Food Res., 22(4), 1347 (2015).

2. C. Yang, W. Du, D. Yang, Int. J. Food Sci. Nutr., 67(7), 818 (2016).

3. T. Herrera, Y. Aguilera, M. Rebollo-Hernanz, et al., Food Sci. Technol., 89, 65 (2018).

4. B. Benelam, L. Wyness, Nutr. Bull., 35(1), 3 (2010).

5. C. Ravikumar, Int. J. Pharm. Pharm. Sci. Res., 6(5), 236 (2014).

6. M. P. A. Carabajal, M. I. Isla, I. C. Zampini, South African J. Bot., 110, 258 (2017).

7. D. Marinova, F. Ribarova, M. Atanassova, J. Chem. Technol. Metallurgy, 40(3), 255 (2005).

8. R. Tsao, Nutrients, 2, 1231 (2010).

9. C. Zhang, C. Li-Chieh Suen, C. Yang, S. Y. Quek, Food Chemist., 244, 109 (2018).

10. D. Del Rio, A. J. Stewart, W. Mullen, et al., J. Agric. Food. Chem., 52(10), 2807 (2004).

11. A.-M. Boudet, Phytochemistry, 68, 2722 (2007).

12. S. L. Al-osaj, Master Thesis, College of Science Department of Biotechnology, Al-Nahrain University, Iraq (2016).

13. K. R. Narayana, M. S. Reddy, M. Chaluvadi, K. Devarakonda, Indian J. Pharmacol., 33(1), 387 (2011).

14. T. Lakshmi, R.V. Geetha, A. Roy, S.A. Kumar, Int J. Pharm. Sci. Rev. Res., 9(2), 136 (2011).

15. I. C. G. Honório, F. P. G. Bonfim, S. G. Montoya, et al., J. Agron., 38(1), 69 (2016).

16. B. Kaya, Y. Menemen, F. Z. Saltan, Pakistan J. Botany, 44(2), 595 (2012).

17. I. Augšpole, M. Dūma, B. Ozola, Agron. Res., 16(3), 892 (2018).

18. R. Cleverdon, Y. Elhalaby, M. D. McAlpine, et al., Beverages MDPI, 4(1), 1 (2018).

19. S. Vitalini, G. Beretta, M. Iriti, et al., Acta Biochim. Pol., 58(2), 203 (2011).

Ingrida Augšpole, Māra Dūma, Ingmārs Cinkmanis, Baiba Ozola

\section{ŽOLELIỤ ARBATOS KAIP FENOLINIŲ JUNGINIŲ ŠALTINIS}

Santrauka

Skysčiu chromatografijos metodu buvo tiriami fenoliniai junginiai žolelių arbatose. Achillea millefolium L. arbatoje identifikuota 14 fenolinių junginių, kuriu bendras kiekis sudaro $136,76 \pm 0,8 \mathrm{mg} 100 \mathrm{~g}^{-1}$, pipirmètes arbatoje $-304,38 \pm 10,7 \mathrm{mg} 100 \mathrm{~g}^{-1}$, Alchemilla vulgaris L. - 319,53 $\pm 12,5 \mathrm{mg} 100 \mathrm{~g}^{-1}$, Calendula officinalis L. $-586,36 \pm 17,6 \mathrm{mg} 100 \mathrm{~g}^{-1}$, Bellis perennis L. $-802,96 \pm 21,3 \mathrm{mg} 100 \mathrm{~g}^{-1}$. 
